\title{
Relationship between early life respiratory illness, family size over time, and the development of asthma and hay fever: a seven year follow up study
}

\author{
Anne-Louise Ponsonby, David Couper, Terence Dwyer, Allan Carmichael, Andrew Kemp
}

Menzies Centre for Population Health Research, University of Tasmania, Australia A-L Ponsonby

D Couper

T Dwyer

Academic Department of General Practice and Community Care, Canberra Clinical School, University of Sydney, Australia A-L Ponsonby

Department of Paediatrics and Child Health, University of Tasmania, Australia A Carmichael

Department of Immunology, Royal Children's Hospital, University of

Melbourne, Australia

A Kemp

Department of Biostatistics, University of North Carolina, Chapel Hill, North Carolina, USA D Couper

Correspondence to: Dr A-L Ponsonby, Academic Unit of General Practice, Canberra Clinical School, Calvary Hospital, PO Box 254, Jamison Centre 2614, Australia

Received 14 September 1998 Returned to author 25 November 1998 Revised manuscript received 20 April 1999

Accepted for publication

26 April 1999

\begin{abstract}
Background-The timing and mechanism of the inverse association between increasing sibling number and atopic disease are not yet understood. A study was undertaken to examine how family size at birth predicts early respiratory illness, to report the association between infant respiratory illness and childhood atopic disease, and to determine whether the protective effect of large family size operates during infancy or later childhood.

Methods-A prospective follow up study was carried out on 863 children $(78 \%)$ of 1111 participants in the Tasmanian Infant Health Survey performed in 1988. In 1988 household size and history of respiratory illness were obtained by parental interview at home (median age 35 days) and later by telephone (median age 85 days). In 1995 asthma, hay fever, and household size were assessed by parental questionnaire in a large cross sectional survey.

Results-In 1988 increasing resident number (per resident) (adjusted odds ratio (AOR) 1.17 (95\% CI 1.05 to 1.31$)$ ) and resident density (AOR 1.77 (95\% CI 1.07 to 2.94)) were related to parental report of an upper respiratory tract infection (URTI) by one month of age. Children with a reported URTI by home interview were more likely to have subsequent asthma (adjusted relative risk (ARR) 1.27 (95\% CI 1.05 to 1.53$)$ ). The association between lower respiratory tract infection (LRTI) at telephone interview (relative risk (RR) $1.34(95 \%$ CI 1.02 to 1.75$)$ and asthma was reduced after adjustment for family history of asthma (ARR 1.27 (95\% CI 0.98 to 1.66)). Antibiotic use by home interview was not associated with subsequent asthma or hay fever. Indicators of family size in $\mathbf{1 9 8 8}$ were associated with hay fever but not asthma but, in contrast, resident number in 1995 was inversely associated with asthma (AOR 0.82 (95\% CI 0.72 to 0.92) per resident) and hay fever (AOR 0.82 (95\% CI 0.71 to 0.96 ) per resident). Children with no siblings were at risk for current asthma, particularly if symptoms
\end{abstract}

began after the age of four (RR 2.81 (95\% CI 1.36 to 5.84)).

Conclusions-The apparent protective effect of large household size and asthma could not be explained by an increase in reported early respiratory illness. The first year of life may not be the most critical time for the protective effect of large household size to be mediated in relation to asthma, but this effect occurred by the seventh year of life.

(Thorax 1999;54:664-669)

Keywords: family size; respiratory infection; childhood; asthma; hay fever

Children of large families have an increased risk of early respiratory infection ${ }^{1}$ and a reduced risk for hay fever ${ }^{2-7}$ and eczema. ${ }^{6}$ Asthma rates have been found to be lower in children of larger families in some studies ${ }^{5} 6910$ but not related to older sibling number ${ }^{7}$ or total sibling number ${ }^{11}$ in others. Children of large families have also shown reduced skin sensitisation $^{2-41213}$ or lower specific IgE levels ${ }^{5}{ }^{14}$ to common aeroallergens.

In 1989 the finding that the older sibling number rather than younger sibling number was more strongly associated with a lower risk of hay fever in a large cohort led to the proposal that infection in early childhood may protect against atopic disease. ${ }^{2}$ Later studies have provided some support for the hypothesis that infections may reduce the development of atopy in childhood. ${ }^{15-18}$ However, parental report of non-specific infection during the first month of life is not associated with a reduction in the incidence of hay fever at age $11-16 .^{3}$

Allergen exposure in early life may prime for subsequent $\mathrm{T}$ cell reactivity. If $\mathrm{T}$ cell selection favours the growth of T helper 1 (Th1) cells, IgA and IgG host responses will be favoured. ${ }^{19}$ However, if $T$ cell selection favours the production of T helper 2 (Th2) cells, IgE production will be promoted, increasing the likelihood of atopic disease..$^{19}$ Repeated bacterial or viral infections might protect against the development of allergic disease by enhancing Th1 responses. ${ }^{19}$ After repeated restimulation a $\mathrm{T}$ cell phenotype becomes dominant, leading to memory $\mathrm{T}$ cells that direct immune responses 
to the allergen throughout later life..$^{19}$ It is not clear which period of early life is most important for this process. A critical window may occur during the first months of life ${ }^{18}$ or a stable state of Th1:Th2 balance may not occur until school age. ${ }^{19}$

\section{Methods}

COHORT STUDY

The cohort study operated from six obstetric hospitals in the state where approximately $93 \%$ of births occurred. All infants born within these hospitals were scored to assess the risk of sudden infant death syndrome (SIDS) using a predictive model based on a composite score of maternal age, birth weight, season of birth, sex, duration of second stage of labour, and type of infant feeding (intention to breastfeed or not). ${ }^{20}$ Singletons with a score over the cut off were eligible to join the survey; multiple births were automatically eligible. Eligible infants represented approximately one fifth of live births in the state. Infants with severe neonatal disease, major congenital anomalies, those placed for adoption, and those expected to reside outside Tasmania were excluded ( $\mathrm{n}=15$ of 1988 cohort).

Data were obtained by research assistants on three occasions. The first interview was conducted in the hospital on the fourth day of life. The second interview was a home visit arranged for the fifth postnatal week (median age at interview was 35 days). Premature infants ( $<37$ weeks), however, were visited at home at 40 weeks post-conceptional age. At the home visit a structured verbal questionnaire was administered by trained interviewers on a large number of parental, infant, environmental, and child care factors. Parents were asked if the infant had had a cold or received antibiotic medication but not whether they had had a chest infection. In addition, the interviewer documented the physical characteristics of the infant's home and bedroom and conducted physical measurements on the infant. The third interview was conducted by telephone, usually with the same parent respondent as for the home visit, to obtain information on infant health. The median age at this interview was 85 days. Parents were asked if the infant had had a cold or chest infection by this stage. In 19881111 of 1307 eligible infants $(85 \%)$ participated in the home interview.

1995 ASTHMA SURVEY

A cross sectional survey was conducted on all children turning seven in 1995 in Tasmania. The questionnaire included questions from the 1968 Tasmanian Asthma Survey ${ }^{21}$ and the International Study of Asthma and Allergy in Children (ISAAC). ${ }^{22} \mathrm{~A}$ total of 6911 children born in 1988 were identified as being resident in Tasmania in 1995. By 31 December 1995 6378 questionnaires had been completed and returned ( $92 \%$ of all eligible children). In addition, exercise challenge lung function testing was conducted at 23 randomly selected schools in Southern Tasmania on 428 children in a manner described elsewhere. ${ }^{23}$ In 1996 the data from this study were record linked to the pre-existing database from the Tasmanian Infant Health Survey. Of the 1111 who participated in the 1988 home interview, 863 (78\%) also participated in the 1995 asthma survey, provided data on asthma status, and agreed to record linkage.

DEFINITIONS

For this paper a positive history of a cold by home interview is termed an early upper respiratory tract infection (early URTI) and by telephone interview an URTI. Chest infection by telephone interview is termed a lower respiratory tract infection (LRTI). A positive response to the ISAAC question "has your child ever had asthma?" is termed asthma. Current asthma denotes a positive response to both this question and the ISAAC question "has your child had wheezing or whistling in the chest in the past twelve months?" We have previously reported that the probability that a child will demonstrate bronchial hyperresponsiveness (BHR) after exercise is significantly associated with positive responses to these questions. ${ }^{23}$ Age of onset refers to the age (in complete years) when the parent reported that episodes of asthma or wheezy breathing began.

\section{STATISTICAL METHODS}

The data were first examined using contingency tables and the Mantel-Haenszel $\chi^{2}$ test. $^{24}$ The relationship between each infant characteristic and early respiratory illness was estimated using logistic regression analysis. ${ }^{24}$ The prevalence rates for asthma and hay fever were calculated by history of early respiratory illness with direct calculation of relative risk and adjustment for multiple confounders using a generalised linear model with a log link function and a binomial error distribution. ${ }^{24}$ The relationships between infant and child family structure and asthma and hay fever were calculated by multiple logistic regression. ${ }^{24}$ This allows a direct comparison of the different effect of family size between the two periods but the odds ratios in table 3 between family size at birth and asthma or hay fever do not approximate the relative risk as the proportion of disease positive subjects is large. ${ }^{25}$ However, the associated $\mathrm{p}$ values are valid. ${ }^{25}$ An assessment of the effect of family size indicators was conducted by using a linear term in the logistic regression model as well as by grouping sibling number into various categories and comparing how they predicted asthma risk in a logistic model. A linear term was retained if the use of dummy variables did not result in an improvement in the likelihood ratio statistic. The respiratory response to exercise was calculated as the post-exercise forced expiratory volume in one second $\left(\mathrm{FEV}_{1}\right)$ expressed as a percentage of the baseline $\mathrm{FEV}_{1}$ and is described in detail elsewhere. ${ }^{23}$ All analyses were performed using SAS version $6.09 .{ }^{26}$

\section{Results}

DISEASE RATES

The proportion of children with asthma ever was $32.4 \%$ (280/863). The prevalence of hay 
Table 1 Factors associated with parental report of early respiratory illness in 1988

\begin{tabular}{|c|c|c|}
\hline Factor & $\begin{array}{l}\text { Adjusted }{ }^{*} \text { odds ratio }(95 \% \text { CI) for } \\
\text { URTI at home interview }\end{array}$ & $\begin{array}{l}\text { Adjusted }{ }^{\star} \text { odds ratio }(95 \% \text { CI) for } \\
\text { LRTI at telephone interview }\end{array}$ \\
\hline First born child & $0.74(0.56$ to 0.98$)$ & $0.63(0.39$ to 1.00$)$ \\
\hline Number of household residents in 1988 (per resident) & $1.17(1.05$ to 1.31$)$ & $1.06(0.89$ to 1.26$)$ \\
\hline $\begin{array}{l}\text { Resident density in } 1988 \text { (increasing resident number } \\
\text { per room) }\end{array}$ & $1.77(1.07$ to 2.94$)$ & $0.86(0.37$ to 2.01$)$ \\
\hline $\begin{array}{l}\text { Family history of asthma (grandparents, mother, father } \\
\text { and siblings) }\end{array}$ & $1.17(0.87$ to 1.56$)$ & 1.57 (1.00 to 2.45$)$ \\
\hline Infant born during winter (during July/August) & 1.91 (1.40 to 2.62$)$ & $2.61(1.62$ to 4.21$)$ \\
\hline Maternal postnatal smoking & $1.47(1.11$ to 1.94$)$ & $1.40(0.89$ to 2.18$)$ \\
\hline Other resident postnatal smoking & $1.45(1.09$ to 1.93$)$ & $1.39(0.89$ to 2.18$)$ \\
\hline Exclusive breast feeding at home interview & $0.60(0.44$ to 0.81$)$ & $0.58(0.35$ to 0.95$)$ \\
\hline Infant sleeps in a room alone at home interview & $0.70(0.51$ to 0.95$)$ & $0.79(0.48$ to 1.30$)$ \\
\hline Infant sex (male) & $1.09(0.80$ to 1.49$)$ & $0.87(0.54$ to 1.41$)$ \\
\hline Infant birth weight $(<2500 \mathrm{~g})$ & $0.72(0.49$ to 1.06$)$ & $0.77(0.43$ to 1.35$)$ \\
\hline
\end{tabular}

^Adjusted for postnatal age at interview.

URTI = upper respiratory tract infection; LRTI $=$ lower respiratory tract infection.

fever was $18.7 \%$ (163/871) and eczema $19.8 \%$ $(172 / 870)$. There was a strong association between hay fever and asthma prevalence (odds ratio (OR) 4.13 (95\% CI 2.93 to 5.80)). Of the 55 children in this study who also participated in the 1995 exercise testing the exercise response was greater in those with asthma ( $\mathrm{n}=15$; median fall $=13.1 \%$ ) than in those without asthma ( $\mathrm{n}=40$; median fall $=$ $7.5 \%$ ) (Wilcoxon test, $\mathrm{p}=0.04$ ).

RELATIONSHIP BETWEEN FAMILY SIZE, OTHER EXPOSURES, AND EARLY RESPIRATORY ILLNESS A history of URTI by home interview was significantly associated with several factors, including those related to family size and domestic crowding (table 1). Lower respiratory tract infection (LRTI) was not as strongly related to family size or domestic crowding and tended to be more common among infants with a family history of asthma.

RELATIONSHIP OF EARLY RESPIRATORY ILLNESS TO SUBSEQUENT ATOPIC DISEASE

Table 2 shows that infants with an early URTI were at increased risk of asthma. There was no association between URTI at telephone interview and asthma. Because some respondents $(\mathrm{n}=70)$ indicated a positive report of a history of a cold at home interview but not at the later telephone interview, the history of a positive report by either home or telephone interview was also examined. It provided similar results to those for a history of URTI by telephone interview in table 2 . Infants with an LRTI were at increased risk for subsequent asthma and hay fever on univariate analysis but this associ- ation was reduced after adjustment for family history of asthma. Antibiotic use by home interview was not associated with subsequent asthma or hay fever (table 2).

RELATIONSHIP BETWEEN FAMILY SIZE INDICATORS IN 1988 AND 1995 AND ASTHMA AND HAY FEVER Table 3 shows that family size in 1995 was inversely related to asthma and hay fever. The odds of having asthma or hay fever decreased with increasing resident number in 1995, increasing sibling number in 1995, and high resident density in 1995. The apparent protective effect of large family size at age seven for asthma and hay fever was not altered by adjustment for the three forms of early illness listed in table 2. Further adjustment for a history of bronchitis or pneumonia by 1995 provided an adjusted odds ratio of 0.84 (95\% CI 0.74 to 0.96$)$ for asthma and 0.79 (95\% CI 0.68 to 0.93 ) for hay fever. After adjustment for family history of asthma, low birth weight, prematurity, breastfeeding, maternal and other resident smoking, increasing resident number in 1995 remained inversely associated with asthma (adjusted odds ratio (AOR) 0.82 (95\% CI 0.72 to 0.92 )) and hay fever (AOR 0.82 ( $95 \%$ CI 0.71 to 0.96$)$ ). After adjustment for these factors, increasing resident number in 1988 was not associated with asthma (AOR 1.05 (95\% CI 0.94 to 1.18$)$ ) but it was associated with hay fever (AOR 0.86 (95\% CI 0.74 to 0.99)). In a two term model resident density in 1995 was significantly associated with asthma (AOR 0.58 (95\% CI 0.41 to 0.80$)$ ) but resident density in 1988 was not inversely related to asthma (AOR 1.37 (95\% CI 1.00 to

Table 2 Relationship between respiratory illness in 1988 and asthma and hay fever in 1995

\begin{tabular}{|c|c|c|c|c|c|}
\hline Exposure & $\begin{array}{l}\text { Proportion of children } \\
\text { with asthma among } \\
\text { exposed (\%) }\end{array}$ & $\begin{array}{l}\text { Proportion of children with } \\
\text { asthma among unexposed } \\
(\%)\end{array}$ & $\begin{array}{l}\text { Relative risk }(95 \% \\
\text { CI) for asthma }\end{array}$ & $\begin{array}{l}\text { Relative risk (95\% CI) } \\
\text { adjusted for family history } \\
\text { of asthma }\end{array}$ & $\begin{array}{l}\text { Adjusted }{ }^{\star} \text { relative risk } \\
(95 \% \text { CI) for asthma }\end{array}$ \\
\hline Early URTI by home interview & $38.7 \%(122 / 315)$ & $28.8 \%(156 / 542)$ & 1.35 (1.11 to 1.63$)$ & $1.30(1.18$ to 1.57$)$ & $1.27(1.05$ to 1.53$)$ \\
\hline Antibiotic use by home interview & $35.1 \%(40 / 114)$ & $31.8 \%(236 / 742)$ & $1.10(0.84$ to 1.45$)$ & $1.04(0.80$ to 1.36$)$ & $1.04(0.78$ to 1.37$)$ \\
\hline URTI by telephone interview & $32.2 \%(151 / 469)$ & $31.1 \%(111 / 355)$ & $1.03(0.84$ to 1.26$)$ & $0.97(0.79$ to 1.19$)$ & $0.96(0.78$ to 1.18$)$ \\
\hline LRTI by telephone interview & $41.1 \%(37 / 90)$ & $30.7 \%(226 / 735)$ & $1.34(1.02$ to 1.75$)$ & $1.27(0.98$ to 1.66$)$ & $1.27(0.97$ to 1.66$)$ \\
\hline Exposure & $\begin{array}{l}\text { Proportion of children } \\
\text { with hay fever among } \\
\text { exposed (\%) }\end{array}$ & $\begin{array}{l}\text { Proportion of children with } \\
\text { hay fever among unexposed } \\
(\%)\end{array}$ & $\begin{array}{l}\text { Relative risk ( } 95 \% \\
\text { CI) for hay fever }\end{array}$ & $\begin{array}{l}\text { Relative risk (95\% CI) } \\
\text { adjusted for family history } \\
\text { of asthma }\end{array}$ & $\begin{array}{l}\text { Adjusted }{ }^{\star} \text { relative risk } \\
(95 \% \text { CI) for hay fever }\end{array}$ \\
\hline Early URTI by home interview & $20.6 \%(66 / 321)$ & $17.8 \%(97 / 544)$ & $1.15(0.87$ to 1.53$)$ & $1.12(0.85$ to 1.49$)$ & $1.04(0.78$ to 1.40$)$ \\
\hline Antibiotic use by home interview & $20.5 \%(24 / 117)$ & $18.5 \%(138 / 747)$ & $1.11(0.75$ to 1.64$)$ & $1.07(0.73$ to 1.57$)$ & $0.95(0.62$ to 1.44$)$ \\
\hline URTI by telephone interview & $19.2 \%(91 / 474)$ & $18.5 \%(66 / 357)$ & $1.04(0.78$ to 1.38$)$ & $0.99(0.75$ to 1.33$)$ & $0.92(0.68$ to 1.23$)$ \\
\hline LRTI by telephone interview & $26.7 \%(24 / 90)$ & $17.9 \%(133 / 742)$ & $1.49(1.02$ to 2.17$)$ & $1.42(0.98$ to 2.07$)$ & $1.26(0.85$ to 1.87$)$ \\
\hline
\end{tabular}

*Adjusted for family history of asthma, exclusive breast feeding at home visit, maternal postnatal smoking, other adult household resident smoking, low birth weight $(<2500 \mathrm{~g})$, prematurity $(<37$ weeks gestation), gas heater in living room, number of household residents in 1995, and age at interview in postnatal weeks. URTI = upper respiratory tract infection; LRTI = lower respiratory tract infection. 
Table 3 Relationship between family size indicators in 1988 and 1995 and asthma ever and hay fever in 1995

\begin{tabular}{|c|c|c|}
\hline Family size indicators & $\begin{array}{l}\text { Odds ratio }(95 \% \text { CI) for } \\
\text { asthma }\end{array}$ & $\begin{array}{l}\text { Odds ratio }(95 \% \text { CI) for } \\
\text { hay fever }\end{array}$ \\
\hline First born & 1.00 (reference) & 1.00 (reference) \\
\hline Birth order $=2$ & $1.00(0.68$ to 1.39$)$ & $0.77(0.52$ to 1.15$)$ \\
\hline Birth order $=3$ & $0.86(0.56$ to 1.33$)$ & $0.62(0.36$ to 1.07$)$ \\
\hline Birth order $=4$ & $0.84(0.45$ to 1.56$)$ & $0.72(0.34$ to 1.53$)$ \\
\hline Birth order $=5$ or more & $0.93(0.58$ to 3.78$)$ & $0.65(0.19$ to 2.27$)$ \\
\hline Increase in resident number in 1988 (per resident) & $1.08(0.96$ to 1.22$)$ & $0.89(0.76$ to 1.03$)$ \\
\hline Increase in resident number in 1995 (per resident) & $0.82(0.73$ to 0.93$)$ & $0.82(0.70$ to 0.95$)$ \\
\hline $\begin{array}{l}\text { Resident density in } 1988>0.8 \text { residents per room, excluding } \\
\text { bathroom and toilet }\end{array}$ & $1.26(0.93$ to 1.71$)$ & 0.67 (0.45 to 0.98$)$ \\
\hline $\begin{array}{l}\text { Resident density in } 1995>0.8 \text { residents per room, excluding } \\
\text { bathroom and toilet }\end{array}$ & $0.61(0.44$ to 0.84$)$ & $0.64(0.43$ to 0.95$)$ \\
\hline Increase in sibling number in 1995 (per sibling) & $0.83(0.71$ to 0.97$)$ & $0.74(0.61$ to 0.89$)$ \\
\hline Increase in older sibling number in 1995 (per sibling) & $1.00(0.87$ to 1.16$)$ & $0.87(0.72$ to 1.04$)$ \\
\hline Increase in older sibling number in 1995 (per sibling)* & $0.96(0.83$ to 1.20$)$ & $0.82(0.68$ to 1.00$)$ \\
\hline Increase in younger sibling number in 1995 (per sibling) & $0.82(0.69$ to 0.97$)$ & $0.84(0.68$ to 1.03$)$ \\
\hline Increase in younger sibling number in 1995 (per sibling)* & $0.81(0.68$ to 0.97$)$ & 0.79 (0.64 to 0.98$)$ \\
\hline
\end{tabular}

$\star$ In a model with older sibling number and young sibling number as separate terms.

1.87). In a two term model both resident density in 1988 (AOR 0.68 (95\% CI 0.47 to 1.05$)$ ) and resident density in 1995 (AOR 0.70 (95\% CI 0.46 to 1.01 )) had a similar effect for hay fever.

AGE AT ONSET

The distribution of age at onset was examined for those with asthma. The mean age at onset did not vary with report of early URTI (2.13 years vs 2.14 years, $\mathrm{p}=0.84$ ) but did vary with history of LRTI with an earlier onset for those with a positive history ( 1.71 years vs 2.23 years, $\mathrm{p}=0.016$.) Age at onset was not related to having recent wheeze $(p=0.67)$. We then calculated the relative risk for current asthma by subgroups of age at onset of asthma or wheezy breathing, with exclusion of those children who developed asthma outside the relevant age group. LRTI was associated with the following relative risk (RR) for current asthma by age at onset of symptoms: under 2 (RR 2.49 (95\% CI 1.30 to 3.68$)$ ); $2-3$ years (RR 1.37 (95\% CI 0.55 to 3.39 )); age 4 or older (RR 0.78 (95\% CI 0.29 to 2.10$)$ ). Only children were associated with the following relative risk for current asthma by age at onset of symptoms: under 2 (RR 1.53 (95\% CI 0.71 to 3.28); 2-3 years (RR 1.10 (95\% CI 0.28 to 4.36$)$ ); age 4 or older (RR 2.81 (95\% CI 1.36 to 5.84 )). The overall risk of current asthma among only children was 1.66 (95\% CI 1.09 to 2.53 ).

\section{Discussion}

Asthma data were collected using previously assessed questions. ${ }^{23}$ The prevalence of asthma in this study is slightly higher than that in the full cross sectional survey. ${ }^{10}$ The major reason for non-response to follow up appeared to be migration; loss to follow up did not differ by report of early respiratory illness, minimising selection bias. A history of early respiratory illness, although prospective, was based on parental interview so the possibility of reporting bias must be considered. Other studies which have been used to support the hypothesis that early infection protects against the development of atopic disease have also been based on historical data and there are no prospective data based on documentation of infection by other means. In this study it is possible that an over-enthusiastic positive response to questions on infant respiratory illness and on asthma created a spurious association between the two. Table 1 provides some reassurance that parents were reporting the history of an URTI by home interview. Factors associated with report of an LRTI had estimates of association with wider confidence intervals, partly reflecting the fact that only $10.9 \%$ of the sample had experienced an LRTI by this time. The association between a family history of asthma and LRTI in table 2 suggests that this outcome may reflect the manifestation rather than the existence of an LRTI. We were unable to examine family size and BHR due to the small sample size. The protective effect of large family size and asthma is unlikely to reflect delayed diagnosis among children of larger families as birth order did not relate to asthma and only children were particularly at increased risk of later onset asthma.

There has recently been considerable interest in several studies which have suggested that early infection or immunostimulation in childhood protects against subsequent atopic disease. It is also possible that this apparent protective effect reflects non-causal pathways. For example, among Guinea-Bissau adults measles infection was associated with a reduction in mite sensitisation ${ }^{15}$ but this might also be explained by an increased mortality from measles in atopic individuals due to the decreased secretion of gamma interferon known to be associated with the atopic state. ${ }^{28}$ An inverse association was reported between tuberculin responses and atopic disorders in Japanese school children ${ }^{17}$ but, as the size of the tuberculin response depends on cytokine secretion, a reduced response could reflect decreased gamma interferon secretion in atopic subjects in response to bacterial antigens. ${ }^{29}$ Tucson children who had more than one nonwheezing LRTI before the age of three had lower IgE levels at six years of age than those with no history of LRTI (OR 0.2), despite having similar IgE cord levels at birth. ${ }^{18}$ However, infants developing non-wheezing LRTI may be less likely to be atopic because of genetic predisposition or lung structure.

Other studies have reported a positive association between early infection and atopic disease. ${ }^{13}{ }^{30-32}$ A cross sectional survey of Aberdeen children aged 10-14 in 1964 found that 
family size was inversely related to atopic disease but the parental recall of the number of infections before the age of three was associated with a trend towards increased asthma risk. ${ }^{6}$ Thus, studies have provided conflicting results on the relationship between early infection and asthma. It has been pointed out that any relationship between infection and atopy depends on a number of factors including timing, anatomical site, dose, protractiveness, exposure to other infections, and host characteristics, ${ }^{17}$ as well as the stage of immunological development and infection type.

The most likely explanations for the association found in our study between early respiratory illness and asthma are that (1) those predisposed to atopy are more susceptible to early respiratory infection, (2) atopy prone infants develop more prominent symptoms with infection (children whose parents reported no illness may still have had a clinically unapparent infection), (3) children who develop a respiratory infection early may also be more likely to develop recurrent respiratory infections, which are known precipitants of asthmatic episodes, or (4) early respiratory infection can prime respiratory tract sensitisation and development of atopy at a critical period in early life. The first two alternatives are supported by the findings that children born into a family with a member with asthma have an increased risk of developing an early LRTI and the association between early respiratory illness and asthma is reduced after adjustment for family history. A follow up study with epidemiological data on family history, family size over time, age at onset of asthma as well as serial measurements on immune responses to identified viral, bacterial, and other antigenic stimuli would be required to provide clear information on the role of infection in immune development.

There has been increasing interest in the possible role of antibiotic administration to infants and atopic disease promotion in view of the possible role of commensal and pathogenic micro-organisms to provide Th1 stimulation during early postnatal life, but information has been limited. In our study no association was found between antibiotic use in the first month of life and childhood asthma or hay fever.

The timing of the apparent protective effect of large family size for hay fever appeared to operate at the infant as well as childhood stage. Family size indicators in 1988 and also in 1995 were inversely related to hay fever, with similar effects for a measure of domestic crowding (resident density) at both time periods. The odds ratio for increasing younger or older sibling number were also similar, although the sample size in this study did not allow a complete examination of this issue. The relationship between increasing older sibling number and hay fever (AOR 0.82 (95\% CI 0.68 to 1.00$)$ ) is of similar strength to that previously reported for the larger study (OR 0.90 $(0.84$ to 0.96$))^{10}$ but is of borderline signifi- cance, partly reflecting the smaller size of this follow up group with an increased likelihood of type 2 error. ${ }^{25}$

This study provides new information on the timing of the protective effect of large family size for asthma. Children with no siblings were particularly more likely to have current asthma if the onset of symptoms was at age four or older. Here, the magnitude and significance of the apparent protective effect of resident number and density for asthma were more evident in 1995 than in 1988 and were independent of these measures in 1988. A dose response trend between increasing sibling number in 1995 and decreasing age at onset of asthma or wheezy breathing was evident in the larger cross sectional study. ${ }^{10}$ These findings suggest that the first year of life may not be the most critical time for the protective effect of large household size to be mediated in relation to asthma.

The asthma study was funded by the Public Health Research and Development Committee of the National Health and Medical Research Council, Australia. A-L Ponsonby held a PHRDC Fellowship. The authors thank participating children, families and schools, the Department of Education, Cultural Asthma Foundation of Tasmania for equipment loan, C Goff for data coordination, collection and exercise testing, J Cochrane for database management, M Martin for exercise testing and for database management, M Martin for exercise testing and volunteer staff V Walsh, B Duffy, D Jackson, V Calvert, D Young and S Clark. The 1988-1995 infant cohort study was supported by the US National Institutes of Health Grant 001 HD2897901A1, Tasmanian State Government, Australian
Rotary Health Research Fund, National Health and Medical Research Council of Australia, National Sudden Infant Death Research Council of Australia, National Sudden Infant Death
Syndrome Council of Australia, Sudden Infant Death Research Foundation of Victoria and other constituent organisations, Community Organisations' Support Program of the Department of Human Services and Health, Zonta International, Wyeth Pharmaceuticals, and Tasmanian Sanatoria After-Care Association. Part of the analysis of this project was supported by a donation from Coles Supermarkets to the Canberra Region Medical Foundation.

1 Leeder SR, Corkhill R, Irwig LM, et al. Influence of family factors on the incidence of lower respiratory illness during the first year of life. Br F Prev Soc Med 1976;30:203-12.

2 Strachan DP. Hay fever, hygiene and household size. BMF 1989;299:1259-60.

3 Strachan DP, Taylor EM, Carpenter RG. Family structure, Strachan DP, Taylor EM, Carpenter RG. Family structure,
neonatal infection, and hay fever in adolescence. Arch Dis Child 1996;74:422-6.

4 Strachan DP, Harkins LS, Johnston ID, et al. Childhood antecedents of allergic sensitization in young British adults. f Allergy Clin Immunol 1997;99:6-12.

5 Jarvis D, Chinn S, Luczynska C, et al. The association of family size with atopy and atopic disease. Clin Exp Allergy 1997;27:240-5.

6 Bodner C, Godden D, Seaton A. Family size, childhood infections and atopic diseases. The Aberdeen WHEASE Group. Thorax 1998;53:28-32.

7 Rasanen M, Laitinen T, Kaprio J, et al. Hay fever, asthma and number of older siblings: a twin study. Clin Exp Allergy 1997;27:515-8.

8 Golding J, Peters T. Eczema and hay fever, In: Butler N, Golding J, eds. From birth to five. A study of the health and behavior of Britain's five-year-olds. Oxford: Pergamon Press, 1986: $171-86$.

9 Rona RJ, Duran-Tauleria E, Chinn S. Family size, atopic Rona RJ, Duran-Tauleria E, Chinn S. Family size, atopic
disorders in parents, asthma in children and ethnicity. $\mathfrak{f}$ disorders in parents, asthma in child
Allergy Clin Immunol 1997;99:454-60.

10 Ponsonby AL, Couper D, Dwyer T, et al. A cross-sectional study of the relationship between sibling number and asthma, hay fever and eczema. Arch Dis Child 1998;79:32833

11 Sears MR, Holdaway MD, Flannery EM, et al. Parental and neonatal risk factors for atopy, airway hyperresponsiveness, and asthma. Arch Dis Child 1996;75:392-8.

12 Von Mutius E, Martinez FD, Fritzsch C, et al. Skin test reactivity and number of siblings. BMf $1994 ; 308.692-5$.

3 Forastiere F, Agabiti, Corbo GM, et al. Socioeconomic stalife as determinants of atopy in children. Epidemiology 1997;5:566-70.

14 Matricardi PM, Franzinelli F, Franco A, et al. Sibship size, birth order, and atopy in 11,371 Italian young men. $\mathcal{f}$ birth order, and atopy in 11,371 Itali
Allergy Clin Immunol 1998;101:439-44.

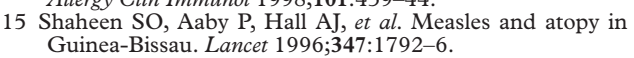


16 Matricardi PM, Rosmini F, Ferrigno L, et al. Cross sectional retrospective study of prevalence of atopy among Italian military students with antibodies against hepatitis A virus. BMF 1997;314:999-1

17 Shirakawa T, Enomoto T, Shimazu S, et al. The inverse association between tuberculin responses and atopic disorder. Science 1997;275:77-9.

18 Martinez FD, Stern DA, Wright AL, et al. Association of non-wheezing lower respiratory tract illnesses in early life with persistently diminished serum IgE levels. Thorax 1995;50:1067-72.

19 Holt PG. A potential vaccine strategy for asthma and allied atopic diseases during early childhood. Lancet 1994;344: 456-8.

20 D'Espaignet ET, Dwyer T, Newman NM, et al. The development of a model for predicting infants at high risk of sudden infant death syndrome in Tasmania. Paediatr Perinat Epidemiol 1990;4:422-35.

21 Gibson HB, Silverstone H, Gandevia B, et al. Respiratory disorders in seven-year-old children in Tasmania: aims,
methods and administration of the survey. Med $f$ Aust methods and

22 Asher MI, Keil U, Anderson HR, et al. International Study of Asthma and Allergies in Childhood (ISAAC): rationale and methods. Eur Respir F 1995;8:483-91.

23 Ponsonby AL, Couper D, Dwyer T, et al. Exercise-induced bronchial hyper-responsiveness and parental ISAAC questionnaire responses. Eur Respir f 1996;9:1356-62.
24 Fisher LD, van Belle G. Biostatistics: a methodology for the Fisher LD, van Belle G. Biostatistics: a methodology for the
health sciences. New York, John Wiley \& Sons Inc, 1993.

25 Armitage P, Berry G. Statistical methods in medical research. 3rd ed. Oxford: Blackwell Scientific Publications, 1994: 422-36. 26 SAS/STAT User's Guide. Version 6. 4th ed. Cary, NC: SAS Institute Inc; 1990: Volumes 1 and 2.

27 Shaw R, Woodman K, Ayson M, et al. Measuring the prevalence of bronchial hyper-responsiveness in children. Int $\mathcal{f}$ Epidemiol 1995;24:597-602.

28 Campbell DE, Kemp AS. Measles and atopy in African children. Lancet 1996;348:825.

29 Campbell DE, Kemp AS. Proliferation and production of interferon-gamma (IFN-gamma) and IL4 in response to Staphylococcus aureus and staphylococcal superantigen in childhood atopic dermatitis. Clin Exp Immunol 1997;107: 392-7.

30 Backman A, Bjorksten F, Ilmonen S, et al. Do infections in infancy affect sensitization to airborne allergens and development of allergic disease? A retrospective study of seven opment of allergic disease? A retrospective

31 Peat JK, Britton WJ, Salome CM, et al. Bronchial hyperresponsiveness in two populations of Australian hyperresponsiveness in two populations of Australian schoolchildren. II. Relative import
factors. Clin Allergy 1987;1 7:283-90.

32 Sigurs N, Bjarnason R, Sigurbergsson F, et al. Asthma and immunoglobulin $\mathrm{E}$ antibodies after respiratory syncytial virus bronchiolitis: a prospective cohort study with matched controls. Pediatrics 1995;95:500-5. 